\title{
A PERSPECTIVE OF THE FAKE NEWS' IMPACT IN THE EMPLOYEE BEHAVIOUR IN THE COVID 19's CRISIS
}

\author{
Cristian Marian RADU ${ }^{a^{*}}$
}

${ }^{a}$ Bucharest University of Economic Studies, Romania

\begin{abstract}
Although statistics from recent years indicate a significant trend of increasing the level of interaction in the online environment between the various representatives of organizations and their stakeholders, the COVID 19 Pandemic has generated an unprecedented escalation of this mean of communication. Threats to human health have been supplemented by the near-complete shutdown of economies and employees and their management have faced situations with an unplanned impact. The same sanitary restrictions that imposed the isolation of people in homes encouraged the predominant use, in communication, of virtual channels and favoured the multiplication of the phenomenon called "fake news".

By collecting and processing published and accessible information in the literature, the paper analyses, from an analytical existential perspective, and through a qualitative interview how to make human decisions in the specific context of the COVID 19 crisis and the impact of these "fake news", propagated with or without intention, on the behaviour of employees and aims to provide some recommendations to the management of these organizations to address the challenges of the coming period.
\end{abstract}

KEYWORDS: coping mechanism, COVID-19 crisis, decision-making mechanism, existential personal analysis, "fake news"

\section{DOI: $10.24818 / \mathrm{IMC} / 2021 / 04.13$}

\section{INTRODUCTION}

The development of information technology in recent years has significantly reconfigured the way of communication in the virtual environment. The speed of the global internet penetration and the declining price-to-technology ratio of software, hardware and smartphones has turned online space into a significant vector of information production and dissemination.

In this context, the beginning of the Covid 19 crisis, in March 2020, brought with it an unprecedented explosion of communication in the virtual space and accelerated the digitization processes of various organizations. For example, in the United States, "the first weeks of March [2020] saw an 18 percent increase in in-home data usage compared to the same period in 2019 [...] causing an unprecedented spike in data traffic" (Johnson, 2021).

The internet is now the favoured used space for "communication, entertainment, and work" (Johnson, 2021) for billions of people around the world.

Employees were forced to stay at home and had to work remotely. Step by step the threat against health was combined with the effect of different public institutions or private organizations decisions as well as a real "Pandemic Disinformation \& Misinformation"1 (n.d.).

All those false, incomplete or excessive information, propagated through internet with or without intention, affected the employee behaviour.

\footnotetext{
*Corresponding author. E-mail address: cristian.radu@euritma.ro, cristian.marian.radu@gmail.com
} 
For a long time, I have been concerned about the impact of various changes on human behaviour. My aim is to conduct research which will allow to integrate and correlate the Existential Analysis literature with other managerial instruments. In this context, the Covid 19 pandemic is an appropriate chance to study and analyse the employee behaviour in those change situations using interdisciplinary issues and models.

There are two questions this article is built upon: "if the" "fake news" impact on human behaviour can be explained by PEA (Personal Existential Analysis) model" (Längle, 2003, p.37-53) and "if an individual who cannot process external "information" will develop a pre-reflexive defence mechanism (coping)" (Lazarus, 1966 and Längle, 1998).

Starting from this question, the paper's aim is to offer an existential analysis understanding of human behaviour in such a crisis and to offer some recommendation for professional managers for facing such a crisis in the future.

\section{THE EXISTENTIAL ANALYSIS' PERSPECTIVE OF THE FAKE NEWS' IMPACT IN THE EMPLOYEE BEHAVIOUR IN THE COVID 19's CRISIS}

\subsection{The methodology applied overview}

Considering the starting questions, the scientific methodology applied is synthesised in the Table 1.

Table 1. The Methodology Overview

\begin{tabular}{|c|c|c|}
\hline & Activity & Details \\
\hline \multirow[b]{2}{*}{1} & \multirow{2}{*}{$\begin{array}{l}\text { Formulate } \\
\text { the hypothesis }\end{array}$} & $\begin{array}{l}\text { When an individual is able to process the "information" of } \\
\text { "fake news", received from external environment, his decision } \\
\text { is following the PEA Model (Längle, 2003, 2017) }\end{array}$ \\
\hline & & $\begin{array}{l}\text { When individual has no resources to process the external } \\
\text { "information" of "fake news" will develop a pre-reflexive } \\
\text { defence mechanism (coping)" (Lazarus, 1966 and Längle, } \\
\text { 2003). }\end{array}$ \\
\hline 2 & Collection and analysis & $\begin{array}{l}\text { Scientific articles, public information ("on-line" and various } \\
\text { databases) published in Romania and international environment } \\
\text { (organizational, public and private) before and during Covid-19 } \\
\text { crisis. }\end{array}$ \\
\hline 3 & Literature research & $\begin{array}{l}\text { Lazarus (1966), Längle (2003, 2017), Elisabeth Kubler Ross } \\
(1969,2014) \text {, Deaconu and Igret (2008) }\end{array}$ \\
\hline 4 & $\begin{array}{l}\text { Analyse } \\
\text { and interpretation behaviour } \\
\text { of a group of nineteen people }\end{array}$ & $\begin{array}{l}\text { The interpretation of the results. Giving a perspective on the } \\
\text { impact of "fake news" in three cases. The behaviour of people } \\
\text { considering correlation among different existing models in the } \\
\text { available literature. } \\
\text { Create a Case Study based on the interview results. }\end{array}$ \\
\hline 5 & Recommendations & $\begin{array}{l}\text { For future quantitative research in order to develop a potential } \\
\text { tool for diagnosing and influencing employee behaviour in } \\
\text { crisis conditions. }\end{array}$ \\
\hline
\end{tabular}

In this respect, the analysis will start with an understanding of the "fake news" phenomenon, generally and in the Covid 19 pandemic, then with literature research, an analysis comparison among different approaches and, finally, with some examples and recommendations. 


\subsection{The emergence and potential impact of "fake news" in the context of the Covid 19 crisis}

As we showed in the introductory section, recent years have shown not only that "high-speed internet coverage" (DG CNECT and Eurostat, 2013, 2020) increased and information has quickly become accessible to the majority of the world's citizens, but also that significant masses of people have become part of the flow of information creation, consumption, filtering and distribution.

"The media oligarchy" (Dice, 2017, p.6) who once controlled information accessible to the general public, like newspapers, TV and radio has been forced to admit that it has lost its monopoly and can no longer control this huge flux of information that is produced and propagated in the online space. Virtually every citizen who owns a smartphone or a video camera, who has access to the internet and access to an Instagram $^{2}$ (n.d.) page has the opportunity to become a producer of information from anywhere and even through live broadcasts. Nowadays large organizations like Google ${ }^{3}$ (n.d.), Amazon $^{4}$, Facebook $^{5}$ (n.d.) or YouTube ${ }^{6}$ (n.d.) "have become major media companies that host and distribute content in quantities previously unimagined" (Dice, 2017, p.7).

The internet virtual channel is actually very professionalized and the specialists consider, counting and regulating the "traffic [...and the] performance evaluation and performance optimization" (n.d.).

Having noticed this trend, organizations have also increased the level of interaction with various stakeholders using increasingly diverse methods and procedures like "add settings" (n.d.).

Throughout this increased flow of communication, organizations have the need to attract the attention of information consumers and direct them to certain websites containing specific commercial advertisements.

However, along with these needs, freelancers and/or companies offer to increase their clients' internet traffic for certain sites, being remunerated according to the number of clicks. After the need to rapidly increase the number of visits to some websites and to create other websites with content similar to established brands and to attract additional visitors for whom they would receive other revenue, was just one step, easily covered.

All these excesses that can be explained in a competitive context have over time been supplemented by the phenomenon of knowingly spreading "fake news"9 (n.d.) in order to obtain certain reactions from the target groups to which they were addressed.

"In 2017 „fake news” became Collins Dictionary's word of the year" (n.d., 2017) meaning: "stories that are not true or are meant to be misleading have been used to make money, change people's views and opinions and make us question who we can trust"11, or, exactly how appeared in 2017's edition of dictionary with the following meaning: "false, often sensational, information disseminated under the guise of news reporting"12.

The phenomenon described by the expression "fake-news" was first exemplified with a disinformation campaign, occurred more than 2000 year ago, when Octavian (son of Julius Caesar) accused his rival, Mark Antony, as having an affair with Cleopatra, the Queen of Egypt, within the Roman Republic civil war.

The "fake news" nowadays represents a postmodernism manifestation, defined as "an attitude of scepticism, irony, or rejection"13 (n.d.) against the official ideology. Many individuals aim to have an opinion and to be free to share that with others and, for this, all virtual channels like Facebook, Twitter or Instagram offer the proper environment.

But this freedom of communication also provided a proper framework for disseminating "fake news", sometimes built specifically to get attention and generate a certain behaviour, a reaction and a certain result, from very clearly defined target groups.

If the impact of this false news was minimized for a while, it began to be carefully studied after the controversies that arose in connection with the election of Donald Trump ${ }^{14}$ (BBC, n.d.), at the end of 2016, as President of the United States of America. Ironically, the way a media trust reported the use of fake news was, in itself, fake news because "Washington Post's Story on Fake News was Fake News" (Dice, 2017, p. 14). 
After heated discussions following the US elections, the public discovered the real impact of controlling the behaviour of some people through false news in the case of the British referendum, known as Brexit where "17.4 million voted to leave and 16.1 million voted to remain" (BBC, 2016). Basically, it turned out that the same company Cambridge Analytica ${ }^{15}$ (n.d.), involved in both the US presidential campaign and the British referendum, has designed, tested and used some controversial algorithms, with which it managed to contact, send personalized messages and persuade a number of about " 3 million voters" (Haynes \& Graham, 2019) in the category of those who had isolated themselves from public life for years.

This has shown that these virtual communication channels are also accessed by subjects who do not use the official media.

In this context, the outbreak of the Covid 19 crisis proved to be a new opportunity for the spread of "fake news". There have been voices (Cassidi, 2020) who argued that this crisis could not be predicted and, as a result, is a "Black Swan" type crisis (Taleb, 2007). Instead, Taleb said in an interview with Bloomberg TV that "the Pandemic isn't a Black Swan but a portent of a more fragile global system" (Avishai, 2020).

In our opinion, even in the conditions in which such a change would have been foreseen and would have avoided the "narrative error" (Taleb, 2007, p.113), which the human mind often tends to manifest, some of the economic, social and political consequences associated with this crisis, which allowed the "democratic legitimation" (Marga, 2021, p.430) of isolating people in their own homes, limiting social contact or accelerating "work from home", could not have been normally accepted in other situation. As a result of all these limitations, people behaviours have been impacted and influenced.

Due to the specific situation, in the case of the Covid 19 Crisis, individuals and organizations had access to information almost exclusively through technology, human interactions being significantly reduced. Therefore, the potential for promoting false news was immediately materialized, certain behaviours as well as without.

At first, confronted with an unexpected and unknown situation any individual needs information to understand the situation and to act accordingly and, from here, there is a need for sensational and getting attention.

Some of this news spread in the online environment was a direct result of the legitimate desire of individuals and organizations to be informed, "to be able to estimate the risks in an integrated manner" (Ciocoiu, 2014) and then to take optimal measures.

Beyond the challenges of individuals who have been prevented from working in a "team" (Lefter and Deaconu, 2008, p.307) or reconfiguring the way they work together, organizations have faced challenges in "management"16 (n.d.). Thus, the tasks performed during the physical isolation forced the employees to work in "virtual teams" (Lefter and Deaconu, 2008, p.311).

A first conclusion highlights the fact that some of this news was produced and distributed by single people, in isolation, out of the desire to attract the attention of other individuals and to be able to interact with them.

Organizations have had to communicate with their stakeholders sometimes exclusively virtually and, as a result, part of the area that favours the emergence of fake news is generated by the need to make money and get additional clicks. "Covid-19 crisis is accelerating an expansion of e-commerce" ${ }^{17}$ (OECD, n.d., 2020).

A second conclusion highlights the fact that another part of these fake news was produced by various organizations out of the desire to popularize their products and obtain a material gain or maximize their market share.

From a third perspective, "fake news" had a geopolitical impact due to the fact that ,all Western countries, as well as Russia and China, threw themselves into a race that went beyond scientific rivalry" $"$ (Vilasanjuan, 2021). 
The fourth major perspective underlines the role of "fake news", produced by individuals and/or different organisations in order to get fans for an objective and/or subjective opposition to vaccination campaigns and use of "Vaccination Certificates"19 (Lee, 2021).

In conclusion, in this first section we showed that the change produced by the Covid 19 pandemic generated the favourable framework for the appearance and proliferation of "fake news". The context of continuous change, at macro-social, organizational, individual level, as well as the multiple uncertainties related to medical, economic, social issues, private life generated changes in behaviour and we were able to identify several works and several authors who could prove causality between "fake news" and human behaviour.

\subsection{An existential analysis perspective on how was the employee behaviour impacted in the context of the Covid 19 crisis}

The behaviour means "the way that someone or something behaves in a particular situation" 20 (n.d.) That means, the behaviour depends on the situation, and, as a result, someone could have different behaviours in different contexts.

The information about the "virus" 21 (n.d.) that generated this crisis demonstrated, once again, that man is a "being of context" (Deaconu and Igret, 2008, p.138) and that, in the context of Covid-19, these "fake news" acted on each of the "eight phenomena that influence our decisions" (Deaconu \& Igret, 2008, pp.136-139).

Also, the elaboration of the human decision is extremely usefully synthesized in Personal Existential Analysis model (Längle, 2003, p.37-53), developed within the modern existential analysis. The "Existential analysis appears as a concept in 1933 [and] was first published by Frankl $^{22}$ in 1938" (Längle, 2005, p.5).

Modern existential analysis, founded by Längle $^{23}$ (n.a.), is the third Viennese school of psychotherapy and is a psychotherapeutic discipline "based on existential philosophy and phenomenology, [... focused on] the concept of existence." (Längle, 2005, p.7).

Since man feels the need for "a meaning of existence" (Frankl, 2004, p.106) man's existence represents "a life full of meaning, built on freedom and accountability, which man feels as his own and in which he understands himself as its co-author". (Längle, 2005, p.7). As a result, in any context, including a Covid-type crisis 19, it is natural for the individual to focus on "his reality, his truth, his own life, his decision and responsibility, his action and commitment" (Längle and Bürgi 2014, p.15). This need requires a permanent fulfilment of the "four fundamental existential motivations". (Längle, 2016, pp.78-81).

The first fundamental existential motivation, abbreviated in the literature under the acronym "FM 1" (Längle, 2013, p.16), involves the meeting of those elements necessary for a human being to "be able to be [...] in this world". (Längle, 2015, pp.5-10). The second fundamental motivation, "FM 2" (Längle, 2013, p.16), refers to meeting the necessary conditions to be "in relation to life" (Längle, 2017, pp.7-19), while the third, "FM 3" (Längle, 2013, p.16), offers man the useful elements to enter "into a relationship with himself" (Längle, 2017, pp.7-9). Finally, the fourth fundamental motivation, "FM 4" (Längle, 2013, p.16), gives man the opportunity to materialize his "will to meaning" (Längle, 2012, pp.30-41), and make rational decisions or make choices according to one's conscience.

When the conditions for the materialization of all these four fundamental motivations are met, man is able to receive a stimulus from the external environment, to perceive it as such, to be able to decode it, to be able to understand it and to give it, in this sense, a meaning. Then, he is able to integrate this stimulus, to validate it through the filter of consciousness and he is able to elaborate his own attitude that materializes in an expression, in a behaviour.

As we showed in the previous section The Covid 19 crisis was a fertile context for the production and spread of "fake news". The most problematic situation occurs when those who produce and 
circulate such fake news know that the approach is manipulative, know exactly what the impact will be and know that those who receive the message have few means to protect themselves of effects. As a result, it is important to have at our disposal theoretical tools and concepts with which we can understand how to influence the behaviour of company employees, both staff and managers. In the following I will present an adaptation of a very useful tool that practitioners in existential analysis work with, called "Personal Existential Analysis" ("PEA") model (Längle, 2003, p.37-53).

\section{Conscience}

The deepest sense of inner agreement

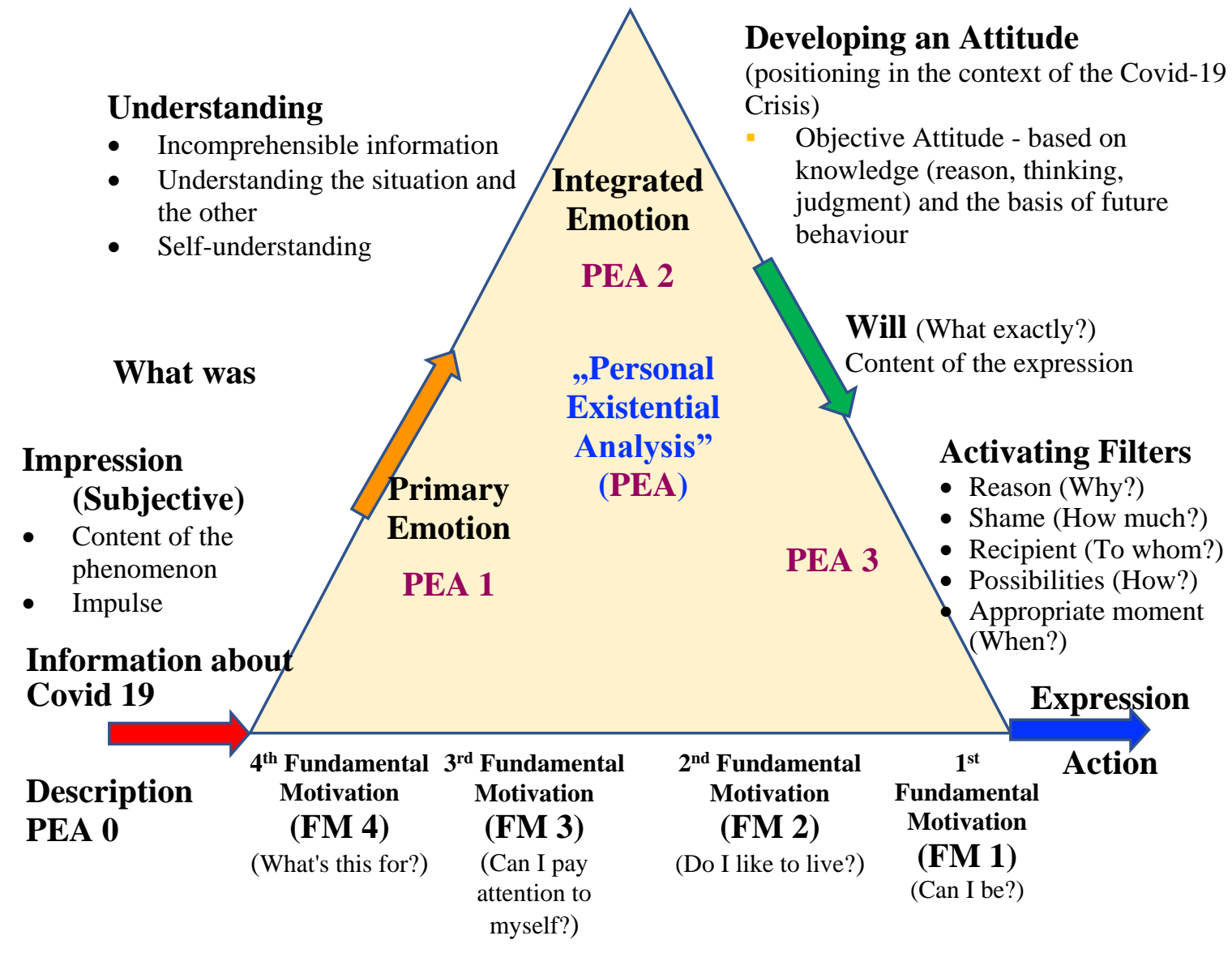

Figure 1. Personal existential analysis (PEA)

Source: adapted from Längle (2003, 2017, p.98)

As we can see in the figure above, the process of making a human decision comprises four distinct stages, one of which ("PEA 0") refers to the process of receiving the stimulus, information and the other three ("PEA 1", "PEA 2" and "PEA 3") refers to the individual's response to the stimulus received. This model could be easily correlated with other "decision stages" described in literature (Deaconu \& Igret, 2008, pp.136-139).

From the very beginning we can see that the impression of receiving the same stimulus is unique and specific to each person. More precisely, beyond the content of the phenomenon, the impression of what was perceived is related to the intensity of the impulse and to the ability to manage the feelings that are triggered.

The more educated a person is, has had access to knowledge, experienced similar situations and learned to understand and manage their feelings, the greater their ability to process and make their own decision. 
Started in the first phase as a medical crisis, the Covid-19 pandemic had and has the peculiarity that the initial information that each individual receives has a strong emotional component, one of the easiest feelings to identify in almost every person being fear.

Confronting an unknown virus, which has imposed the total isolation of humanity, it is natural to access feelings of defence and survival. Then, the crisis evolved and was complemented by an economic crisis, consisting of the loss of jobs, contracts, markets and customers.

Therefore, in the "Primary Emotion" stage we can often identify the feeling of fear that everyone experiences and manages differently. On the other hand, in the third stage, the processing and integration of emotion, we have a first phase that refers to the understanding of the phenomenon.

The higher the level of education of the affected person, the more likely it is that, at a rational level, he will show an understanding of the situation and be able to process it. On the other hand, if the emotional component is very strong, it is possible that this emotion will block the rational understanding and decoding of the stimulus.

Regarding the way of processing a fake information received through a virtual channel we can distinguish three possible situations. In the first of these, the individual manages to process it and identify its character as being "fake news", either by referring to previously known content or by "detecting [it] on Web Search Engines" (Mazzeo, Rapisarda \& Giufrrida, 2021).

We can also identify the situation in which the information, although false, is considered credible to the individual and, based on it, develops an erroneous decision. It is the situation in which the individual's decision is elaborated, that means he has the resources to give his own answer, but he does it based on information whose content is manipulated.

However, there is also a situation in which the information received cannot be processed, either it generates an uncontrollable emotion or the individual does not have other content available to refer to. In the latter case, the individual cannot make his own decision.

When situations arise, that man cannot process Lazarus ${ }^{24}$ (n. a.) has identified the fact that, successively, 4 stages of pre-reflexive defence mechanisms, called "copings" (Lazarus, 1966), can be installed. One "coping reaction" is a "pre-reflexive" defence mechanism, uncontrollable, of the human being when he faces a new situation that he cannot control (he does not understand it, he cannot process it, he does not have the necessary means to action, cannot manage it emotionally and naturally. Similarly, (Längle, 1/1998, pp.16-27) identified that each fundamental existential motivation corresponds to four hierarchical sets of coping mechanisms as shown in Figure 2:

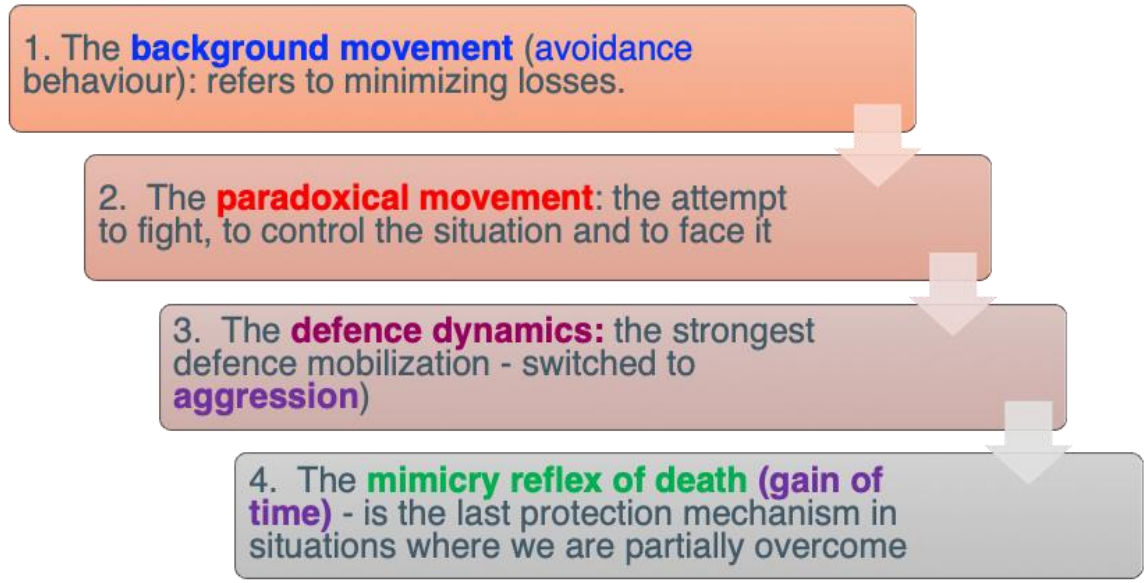

Figure 2. The 4 hierarchical sets of coping mechanisms of existential analysis

Source: adapted from Längle (1/1998, GLE, pp.16-27)

On the other hand, Kübler -Ross ${ }^{25}$ (n.a.) identified the fact that a person goes through four "stages denial, anger, bargaining, depression”) (Kübler-Ross 1969, 2014) (Kübler-Ross \& Kessler, 2014, p.7) until he reaches a fifth stage of "acceptance", when it must consist of "learning to live with the 
one we lost" (Kübler-Ross \& Kessler, 2014, p.7). This framework reflects a similar model as the Lazarus' and Längle's ones.

In my opinion, by combining these models, as presented in Figure 3, we can see that when an individual does not have the resources to cope with the information he receives from the external environment, he either cannot manage his emotionality, or he can understand whether the meaning has been distorted and the pre-reflexive defence mechanisms are activated.

\section{Consciousness is not accessed}

The inner agreement does not end up being

\section{Non-understanding of information}

- Incomprehensible information

- Non-understanding of the situation and / or non-understanding of the other

- $\quad$ Self-non-understanding

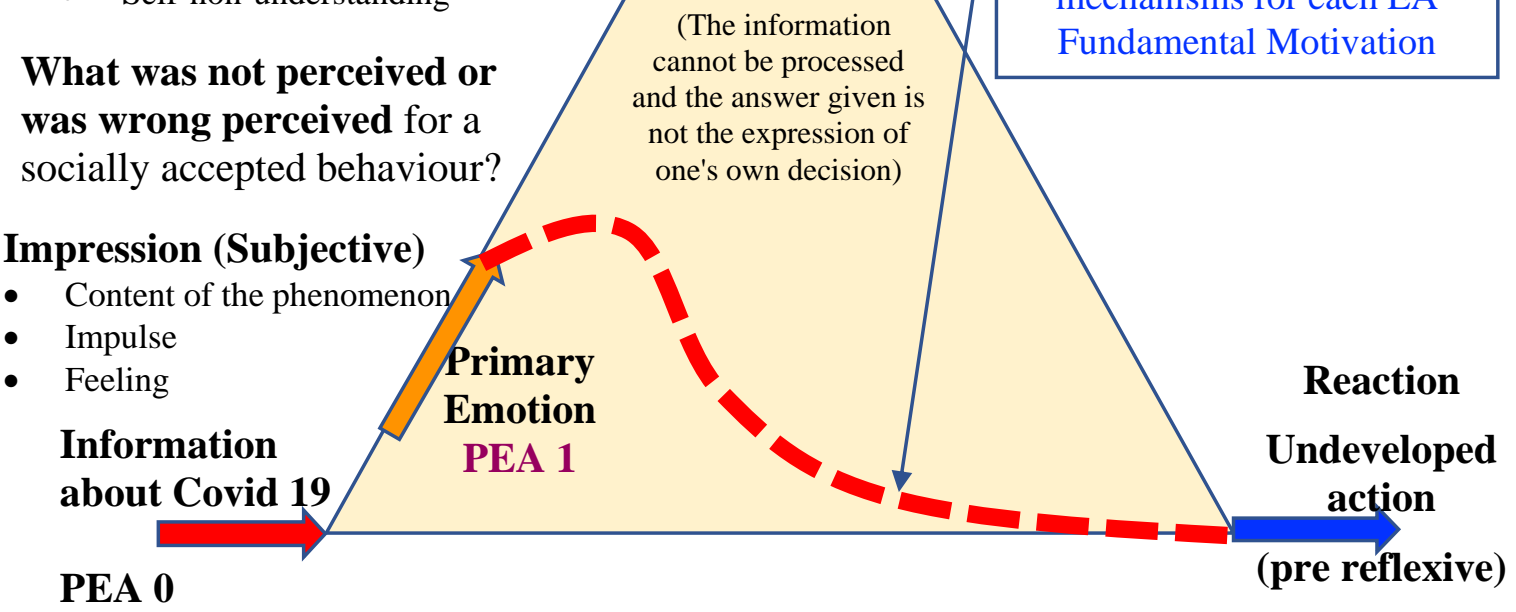

Figure 3. The process of installing a pre-reflexive defence mechanism in case of impossibility to process information about Covid 19

Source: adapted from Längle (2003, 2017, p.98), Lazarus (1966), Kübler-Ross (1969, 2014) and Kübler-Ross and Kessler $(2005,2014)$

As represented in the Figure 3, in such a situation the control of that individual decision is lost and the behaviour represents a reaction. In fact, the pre-reflexive mechanism was installed and the results are uncontrolled behaviours.

\subsection{A case study of how "fake news" impacted the employee behaviour in the context of the} Covid 19 crisis

I will exemplify with a short case study how this human decision-making process can be understood when "fake news" impacted, in all those three different ways, a team of employees at a furniture factory from Olt County, Romania, in the context of the Covid-19 pandemic. The context of the Case Study is shown in the |Figure 4, as follows: 


\begin{abstract}
Context:
"The "CM" factory has about 52 employees, among them 6 have managerial responsibilities and the other 46 people are staff.

During the first period of crisis, between $15^{\text {th }}$ of March until $15^{\text {th }}$ of May 2020, all of them have respected all the authorities' requests to wear a protective mask and to keep social distance at work. Then, step by step, the sanitary measures relaxed and the flow of activities in the factory returned to normal.

However, between October and November 2020, the factory was closed for almost 3 weeks because there was an outbreak of Covid 19, eight of the employees being ill, including the general manager. One of them developed a severe form of the disease, being hospitalized for more than six weeks.

In this context, the general manager, a lady, declared, unofficially, to the other 5 managers, that she will no longer be able to afford to endure such a period without activity in which she will still have to pay the staff and that when a vaccine will be available, all staff, starting with her will be required to be vaccinated.

At the end of June 2021, the vaccine was already available to the entire population of Romania but the level of availability for vaccination had begun to decline alarmingly. In this context, the general manager organized a vaccination campaign for employees inside the medical office at the company's headquarters.

The administrative manager, who had been given the task of organizing the vaccination flow, verbally told the employees, joking according to his statement, that ,those who will not be vaccinated will be fired."

In this situation, one of the employees took the keys of one of the company's managers' cars, simply ran away from the factory, ending up totally damaging the vehicle in a traffic accident.

In the investigation which followed, the employee stated that "given that we were subjected to a mass experiment by dark forces, he could not afford to be vaccinated, even if it meant losing his job".
\end{abstract}

\title{
Figure 4. A case study - the effect of a Fake News
}

The General Manager asked me, as a management consultant, if I can explain somehow the behaviour of that employee, considering the fact that his performance it is very good and it works more than 10 years for the company.

First, I explained that the fact all of them respected the sanitary rules all the Pandemic until that moment means that all of them can process decision in a rational and assertive manner.

Then, during the pandemic there were a lot of debates regarding the vaccine itself and whether the decision to be vaccinated or not should be personal. It is possible that the behaviour from that day to be only the effect of the fear and different arguments, true and/or fake, argued in the public space or could be also triggered by the administrative manager's declaration.

I asked the permission to have a qualitative interview with few of the employees, including the one who create the car accident. The interviews were conducted between October 11-13, 2021 and analysed the behaviour of the nineteen people, using two questions, one closed and one open.

The closed question addressed was: "Has your decision, to be vaccinate or not, been influenced by the administrative manager's statement?"

Fourteen of them answer "No" and for five of them, including the person who create the accident, answer was "Yes".

Then I asked them to detail the reason they answered with "Yes" or "No".

All those fourteen who answered "No" argued that they understood immediately that the administrative manager statement is a joke, due to the fact, the general manager never imposed them something against their free will. Analysing their answer with the PEA tool. from Figure 2, 
their answers evidenced that even they received a false external information, a "fake news" ("the general manager will fire them"), they immediately understood the joke and act accordingly, decided, by their own, to be vaccinate.

Those four who answer "Yes" argued that they took very seriously the administrative manager statement, they did not understand that it is a joke, and, even though their initial intentions were to wait a while with the vaccine, they decided on that moment to be vaccinated, considering that they cannot assume the risk to lose their job. Applying Längle's EPA model here, too, we can see that they have gone through a decision-making process and adopted their own elaborate behaviour. In the process, however, their decision was influenced by the content of the "fake news", which was not understood as a joke.

The person who made the accident stated that "when he heard the statement of the administrative director, he was not afraid that he would lose his job but he felt that he was simply in trouble, that he could no longer be there, in that place, and that the danger of being vaccinated and thus falling into the trap of occult forces that want to subjugate humanity is imminent. As a result, he realized that he had taken the keys to that car and fled with it only after destroying the car, which he hit by a tree on the side of the road, near the entrance gate to the factory yard".

Interpreting this answer with the tool provided in the Figure 3, we can see that person cannot process the information, and a pre-reflexive mechanism was installed. In fact, his behaviour was not elaborate, was a reaction, the first coping mechanism of the first Fundamental Motivation, "a background movement [which reflect] an avoidance behaviour or a flight" (Längle, 2005, p.17).

His belief that occults forces could take control of him induced a greater fear than the fear of losing his job and this inner psychological pressure was relieved by a coping mechanism.

In this case we can also see that, in a situation with a significant emotional charge, such as the imminence of vaccination, a joke can have harmful consequences, being misunderstood and interpreted as such. To the additional question related to the source of his information related to the "occult forces" that would seek to subjugate humanity, the employee confessed not only that he subscribes to many sites and newsletters that promote various conspiracy theories but also actively browses internet at least two hours a day looking for such information. Such a statement indicates that the impact of such false news can occur in several stages: accessing and assuming "erroneous" content, validating it over time, and using it as a "truth and credible source" when another external stimulus will create additional psychological pressure.

This last aspect was a serious lesson, for the whole managerial team, regarding the potential impact of their behaviour in front of employees.

\section{CONCLUSIONS}

The purpose of this article was to provide an existential analytical perspective on the impact that "fake news" can have on an employee behaviour, in the context of Covid 19 Crises.

To support this aim, I formulated two hypotheses, I collected and analysed different scientific articles, I collected and critically analysed the available scientific literature, and I have evaluated and interpreted the behaviour of a group of nineteen people.

As a result, I found some similarities referring to the human decision mechanism treated by Deaconu \& Igret (2008) and Langle's (2003) models. Also, combining Längle's (2003) EPA model with Lazarus' (1966) coping mechanism, the Längle's 4 sets of coping (1998) and Kübler-Ross and Kessler (2014) model I proposed a theoretical model represented in the Figure 3. Finally, I tested and validated that model through qualitative research conducted in a furniture factory.

As a positive result I can point out that model validated those initial hypotheses. 
First, the results of the qualitative interview proved that the first hypothesis is validated, that means "when an individual is able to process the "information" of "fake news", received from external environment, his decision is following the PEA Model (Längle, 2003, 2017)".

Here, I Identified during the research that one individual could either identify that the information is a "fake news" and decide accordingly, either not understanding the manipulative content of the "fake news" and decide considering as a true that content of that "fake news".

Also, the results of the qualitative interview proved that the second hypothesis is also validated, that means "when individual has no resources to process the external "information" of a "fake news" will develop a pre-reflexive defence mechanism (coping)”. (Lazarus, 1966 and Längle, 2003).

Also, here I identified the fact that the "fake news" impact could be cumulative in time, each of them being transforming in a "true" argument and being used for validating a new false one.

Those research conclusions could be also affected by several limitations.

First, the validation of those hypotheses was done using qualitative research. For this is needed to compare and complete with a result of a future quantitative research

Secondly, the number of respondents is very small. In fact, those nineteen respondents are only $36,53 \%$ from the total number of employees, active in the same factory, same industry and same cultural environment. Is it possible that a large number of respondents to offer different results?

Third, the study was conducted in a single factory from one industry. This fact, cannot reflect whether this company is a specific cultural environment in which specific "fake news" could have one specific impact or that results could be generalised to the whole industry.

Fourth, the study could be conducted at a national level, and applied in different industries. Is it possible that kind of impact of "fake news" to be singular or could it require special measures?

Fifths, the research was situational one, due to the fact that the behaviour is also situationally elaborated. Future research could start with identifying the major cultural behavioural similarities and testing those. Otherwise, a single organizational environment and a single organizational culture can lead only to a specific conclusion.

Sixths, the research revealed only the installing, in that specific situation, of a single coping mechanism, more exactly the first coping corresponding to the first fundamental motivation of Längle (1998). Future research should validate each of those sixteen defence copings specific to the Existential Analysis, four for each of those four Fundamental Motivation (Längle, 1998, 2003, 2005, 2012, 2013, 2015 2016, 2017).

The last limitation also offers a very important question which can be validated or invalidated through future scientific research: "If the Elisabeth Kubler Rose model is a particular case of Längle theory, corresponding of installing of the set of four copings in the $2^{\text {nd }}$ Fundamental Motivation".

\section{REFERENCES}

Ads Settings (n.d.). In Ads Settings. Retrieved October 20, 2021, from https://adssettings.google.com

Alfried Längle (n.d.). In Wikipedia. Retrieved October 20, 2021, from https://de.wikipedia.org/wiki/Alfried_Längle

Amazon (n.d.). In Wikipedia. Retrieved October 20, 2021, from https://en.wikipedia.org/wiki/Amazon_(company)

Avishai, B. (2020). In New Yorker. Retrieved October 20, 2021, from https://www.newyorker.com/news/daily-comment/the-pandemic-isnt-a-black-swan-but-aportent-of-a-more-fragile-global-system

Behaviour (n.d.). In Cambridge Dictionary, Retrieved October 20, 2021, from https://dictionary.cambridge.org/dictionary/english/behaviour

Brexit results (2016). In $B B C$. Retrieved October 20, 2021, from https://www.statista.com/statistics/570118/eu-referendum-results/ 
Cambridge Analytica (n.d.). In Wikipedia. Retrieved October 20, 2021, from https://en.wikipedia.org/wiki/Cambridge_Analytica

Cassidi, J. (2020). In New Yorker. Retrieved October 20, 2021, from https://www.newyorker.com/news/our-columnists/as-coronavirus-spreads-stocks-fall-againand-the-white-house-frets-about-a-black-swan

Ciocoiu, N. (2014). Managementul riscului. O abordare integrată, București: Editura ASE.

Deaconu, A., Igreț, R.Ș., coord. (2019). Provocări pentru managementul resurselor umane in organizațiile moderne - Aptitudini manageriale, București.

Dice, M. (2017). The True Story of Fake News, The Resistance Manifesto Publishing, San Diego.

E-commerce (n.d., 2020). In OECD, Retrieved October 20, 2021, from https://www.oecd.org/coronavirus/policy-responses/e-commerce-in-the-time-of-covid-19$3 \mathrm{a} 2 \mathrm{~b} 78 \mathrm{e} 8 /$

Elisabeth Kübler-Ross (n.d.). In Wikipedia. Retrieved October 20, 2021, from https://en.wikipedia.org/wiki/Elisabeth_Kübler-Ross

Facebook (n.d.). In Wikipedia. Retrieved October 20, 2021, from https://en.wikipedia.org/wiki/Facebook

Fake news (n.d.). In BBC. Bitesize. A brief history of ,fake news”. Retrieved October 20, 2021, from https://www.bbc.co.uk/bitesize/articles/zwcgn9q

Fake news (n.d.). In Collins Dictionary. Retrieved October 20, 2021, from https://blog.collinsdictionary.com/language-lovers/collins-2017-word-of-the-year-shortlist

Fake news (n.d.). In Wikipedia. Retrieved October 20, 2021, from https://en.wikipedia.org/wiki/Fake_news

Frankl, V. E. (2004). Man's Search for Meaning, London.

Google (n.d.), In Wikipedia. Retrieved October 20, 2021, from https://en.wikipedia.org/wiki/Google Hayes, T., \& Graham, J. (2019). Brexit, Retrieved October 20, 2021, from https://www.imdb.com/title/tt8425058/.

High-speed internet coverage (n.d.). In DG CNECT and Eurostat. Retrieved October 20, 2021, from https://ec.europa.eu/eurostat/web/products-datasets

Instagram (n.d.). In Wikipedia. Retrieved October 20, 2021, from https://en.wikipedia.org/wiki/Instagram

Internet traffic engineering (n.d.). In Wikipedia. Retrieved October 20, 2021, from https://en.wikipedia.org/wiki/Internet_traffic_engineering.

Johnson, J. (2021). Coronavirus: impact on online usage in the U.S. - Statistics \& Facts. Statista. Retrieved October 25, 2021, from: https://www.statista.com/topics/6241/coronavirus-impacton-online-usage-in-the-us

Kübler-Ross, E. (1969, 2014). On Death and Dying, New York.

Kübler-Ross, E., \& Kessler, D. (2005, 2014). On Grief and Grieving, New York.

Lazarus, R. S. (1966). Psychological stress and the coping process, New York.

Längle, A. (1998). Verständnis und Therapie der Psychodynamik in der Existenzanalyse. GLE/Vol $1 / 1998$, Vienna.

Längle, A. (2003). The Method of „Personal Existential Analysis”, European Psychotherapy/Vol. 4 No. 1, 37-53.

Längle, A. (2005). Existenzanalyse. Grundlagen, Vienna. Asociatia SAEL Romania (2019), Bucuresti.

Längle, A. (2012). Existenzanalyse. Vierte Grundmotivation, Vienna. Asociatia SAEL Romania (2019), Bucuresti.

Längle, A. (2013). Existenzanalyse. Klinische Praxis - Einführung, Vienna. Asociatia SAEL Romania (2019), București. 
Längle, A. (2015). Existenzanalyse. Erste Grundmotivation, Vienna. Asociatia SAEL Romania (2019), Bucuresti.

Längle, A. (2016). Existenzanalyse, Existentielle Zugänge der Psychotherapie, Vienna.

Längle, A. (2017). Existenzanalyse. Dritte Grundmotivation, Vienna. Asociatia SAEL Romania (2019), Bucuresti.

Längle, A. (2017). Existenzanalyse. Zweite Grundmotivation, Vienna. Asociatia SAEL Romania (2019), Bucuresti.

Längle, A., \& Bürgi, D. (2014). Existentielles Coaching, Theoretische Orientierung, Grundlagen und Praxis für Coaching, Organisationsberatung und Supervision, Vienna.

Lee, T. L. (2021). In e Cambridge University Press, COVID-19 Vaccination Certificates and Their Geopolitical Discontents, Retrieved October 20, 2021, from

https://www.cambridge.org/core/journals/european-journal-of-risk-regulation/article/covid19vaccination-certificates-and-their-geopolitical-discontents/

Lefter, V., Deaconu, A., coord. ș.a. (2018). Managementul resurselor umane. Teorie si Practica Managementul echipei, București.

Management. (n.d.). In Wikipedia. Retrieved October 20, 2021, from http://en.wikipedia.org/wiki/Management

Marga, A. (2021). Statul actual, Bucuresti.

Mazzeo, V., Rapisarda, A., \& Giuffrida, G. (2021). Detection of Fake News on COVID-19 on Web Search Engines, In Frontier in Physics, https://doi.org/10.3389/fphy.2021.685730, Retrieved October 20, 2021, from https://www.frontiersin.org/articles/10.3389/fphy.2021.685730/full

Pandemic Disinformation \& Misinformation (n.d.). In Fake News: Develop Your Fact-Checking Skills, Retrieved October 20, 2021, from https://researchguides.ben.edu/fake-news/pandemic

Postmodernism (n.d.). In Wikipedia. Retrieved October 20, 2021, from https://en.wikipedia.org/wiki/Postmodernism

Richard Lazarus (n.d.). In Wikipedia. Retrieved October 20, 2021, from https://en.wikipedia.org/wiki/Richard_Lazarus

Taleb, N. N. (2009). Lebada neagra: Impactul foarte putin probabilului, Bucuresti.

US Election (n.d.). In BBC, News. Retrieved October 20, 2021, from https://www.bbc.com/news/election/us2016/results

Viktor, Frankl (n.d.). In Wikipedia. Retrieved October 20, 2021, from https://en.wikipedia.org/wiki/Viktor_Frankl

Vilasanjuan, R. (2021). In ARI 32/2021, COVID-19: the geopolitics of the vaccine, a weapon for global security,

http://www.realinstitutoelcano.org/wps/portal/rielcano_en/contenido?WCM_GLOBAL_CON TEXT=/elcano/elcano_in/zonas_in/ari32-2021-vilasanjuan-covid-19-the-geopolitics-of-thevaccine-a-weapon-for-global-security

World Health Organization (n.d.). In WHO. Retrieved October 20, 2021, from https://www.who.int/emergencies/diseases/novel-coronavirus-2019

YouTube (n.d.). In Wikipedia. Retrieved October 20, 2021, from https://en.wikipedia.org/wiki/YouTube

\section{ENDNOTES:}

\footnotetext{
${ }^{1}$ https://researchguides.ben.edu/fake-news/pandemic

${ }^{2}$ https://en.wikipedia.org/wiki/Instagram

${ }^{3}$ https://en.wikipedia.org/wiki/Google

${ }^{4}$ https://en.wikipedia.org/wiki/Amazon_(company)

${ }^{5}$ https://en.wikipedia.org/wiki/Facebook
} 
${ }^{6}$ https://en.wikipedia.org/wiki/YouTube

${ }^{7} \mathrm{https}$ ://en.wikipedia.org/wiki/Internet_traffic_engineering.

${ }^{8}$ https://adssettings.google.com

${ }^{9} \mathrm{https} / / /$ en.wikipedia.org/wiki/Fake_news

${ }^{10} \mathrm{https}$ ///blog.collinsdictionary.com/language-lovers/collins-2017-word-of-the-year-shortlist

${ }^{11} \mathrm{https} / / / \mathrm{www} . b b c . c o . u k /$ bitesize/articles/zwcgn9q

${ }^{12} \mathrm{https} / / / \mathrm{blog}$.collinsdictionary.com/language-lovers/collins-2017-word-of-the-year-shortlist

${ }^{13} \mathrm{https} / / /$ en.wikipedia.org/wiki/Postmodernism

${ }^{14} \mathrm{https}: / / \mathrm{www} \cdot$ bbc.com/news/election/us2016/results

${ }^{15} \mathrm{https}: / /$ en.wikipedia.org/wiki/Cambridge_Analytica

${ }^{16} \mathrm{http}: / /$ en.wikipedia.org/wiki/Management

${ }^{17} \mathrm{https} / /$ www.oecd.org/coronavirus/policy-responses/e-commerce-in-the-time-of-covid-19$3 \mathrm{a} 2 \mathrm{~b} 78 \mathrm{e} 8 /$

${ }^{18} \mathrm{http} / / /$ www.realinstitutoelcano.org/wps/portal/rielcano_en/contenido?WCM_GLOBAL_CONTEX T=/elcano/elcano_in/zonas_in/ari32-2021-vilasanjuan-covid-19-the-geopolitics-of-the-vaccinea-weapon-for-global-security

${ }^{19} \mathrm{https} / /$ www.cambridge.org/core/journals/european-journal-of-risk-regulation/article/covid19vaccination-certificates-and-their-geopolitical-discontents/

${ }^{20} \mathrm{https}$ //dictionary.cambridge.org/dictionary/english/behaviour

${ }^{21} \mathrm{https} / / / \mathrm{www}$. who.int/emergencies/diseases/novel-coronavirus-2019

${ }^{22} \mathrm{https}$ ://en.wikipedia.org/wiki/Viktor_Frankl

${ }^{23} \mathrm{https} / / /$ de.wikipedia.org/wiki/Alfried_Längle

${ }^{24} \mathrm{https} / / /$ en.wikipedia.org/wiki/Richard_Lazarus

${ }^{25}$ https://en.wikipedia.org/wiki/Elisabeth_Kübler-Ross 